\title{
Angst+ / Fear+ Introducing a new blog series
}

Erschienen in: ANGST + | FEAR + Von: Blogredaktion

Once upon a time ... in pre-pandemic days, a group of $\mathrm{KWI}$ fellows planned a "Festival of Fear", an event lasting a whole term, designed to explore new formats and collaborations through diverse interactions with colleagues, new fellows and guests, as well as our audiences in Essen and the region. As an object of cultural studies, fear has been examined in many ways: as epistemology and economy, in different semantic and historical contexts, and even as a "lust for fear", including specific spaces and atmospheres, aesthetic manifestations and medial representations. ${ }^{1}$

Amid our planning, the Covid-19 pandemic unexpectedly hit, not unlike the rush of cold water and squirming fish that surprisingly flushes "the youth who went forth to learn what fear was" 2 at the end of a famous German fairy tale, ultimately leaving him "shuddering" (fig. 1).

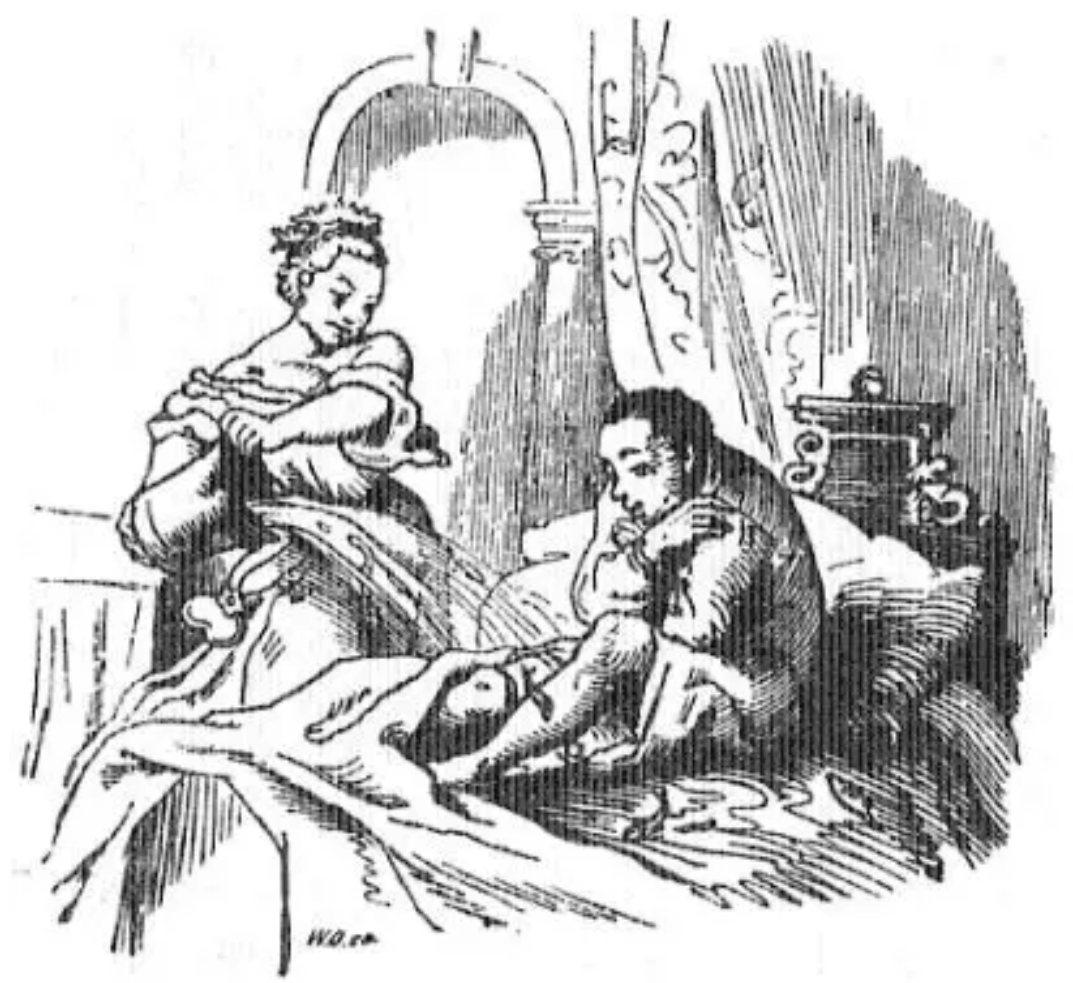

Fig. 1: Illustration for "The Story of the Youth Who Went Forth to Learn What Fear Was" by Ludwig Richter $(1853)^{3}$ 
Against the backdrop of the pandemic, it seemed frivolous to pursue our original plan for a "Festival of Fear", given the way this emotion was gradually sweeping the globe and filling the imagination with all sorts of dread. Again, beautifully visualized over the decades in illustrations of the tale about the boy setting out to study fear:

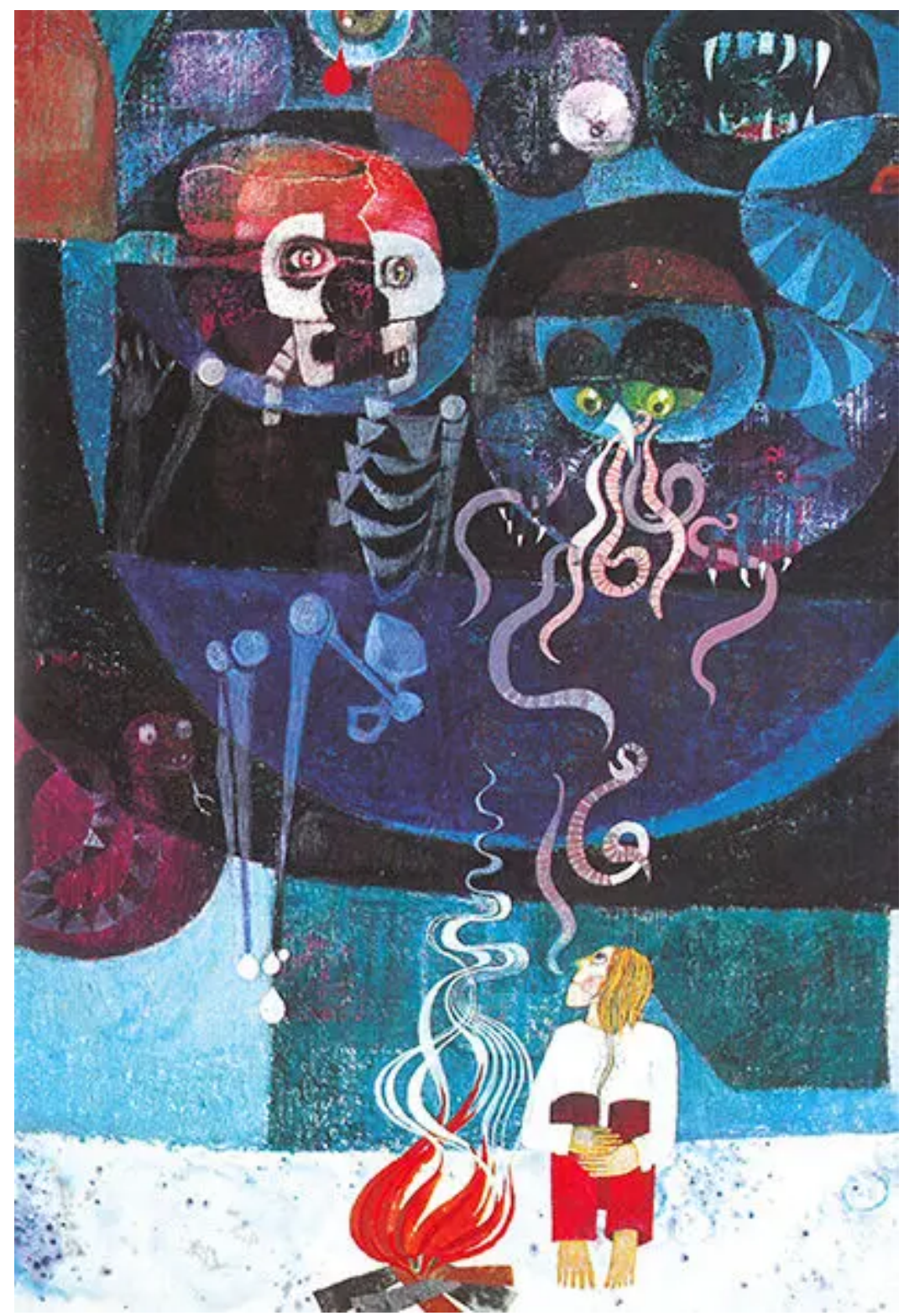

Fig. 2: Illustration for "The Story of the Youth Who Went Forth to Learn What Fear Was" by Marlene Reidel $(1975)^{4}$

With our original title, we wanted to explore a cluster of ambiguous phenomena not only as a problem or psychological condition but also as something potentially desirable, as a resource, as a productive state, in a similar spirit to the Grimms' hero who is quite comfortable conversing with hanged men, playing poker games with giant black cats or bowling with skulls. 


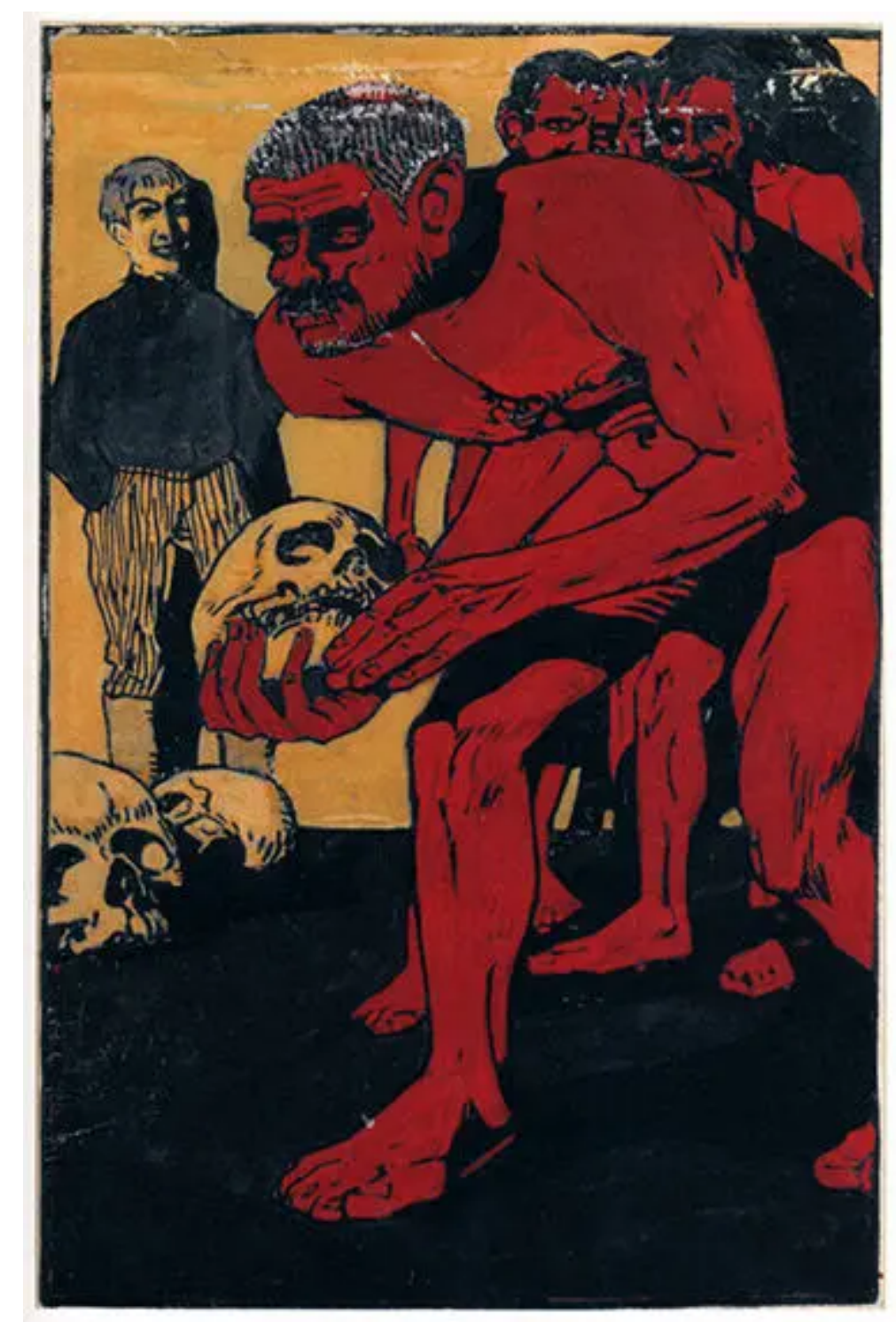

Fig. 3, Illustration for "The Story of the Youth Who Went Forth to Learn What Fear Was" by Albert Weisgerber (around 1910) ${ }^{5}$

In the summer of 2021, after months of anxiety and despair, rapidly alternating modes of suspension and relief, and tenderly rising hopes in parallel with severe social, cultural and economic challenges yet to come, we are slowly adjusting to a new sense of normality. In this moment of transition, we want to revisit and reformulate our fascination with fear and connect it to a range of literary, cultural, social and political phenomena, equally embracing its often overlapping connotations of uncertainty and allure, stasis and productivity. Our new title, „Fear+“, reflects our aim to engage with this emotion without letting it have the final word.

We invite you to join us on a journey through the multifaceted emotional landscape of fear in the coming months, which will feature a series of events and a new series on our blog, including contributions in German or English.

We are excited to launch this new series today with an essay by Hartmut Böhme reflecting on biological, cultural and existential-philosophical patterns of fear. 


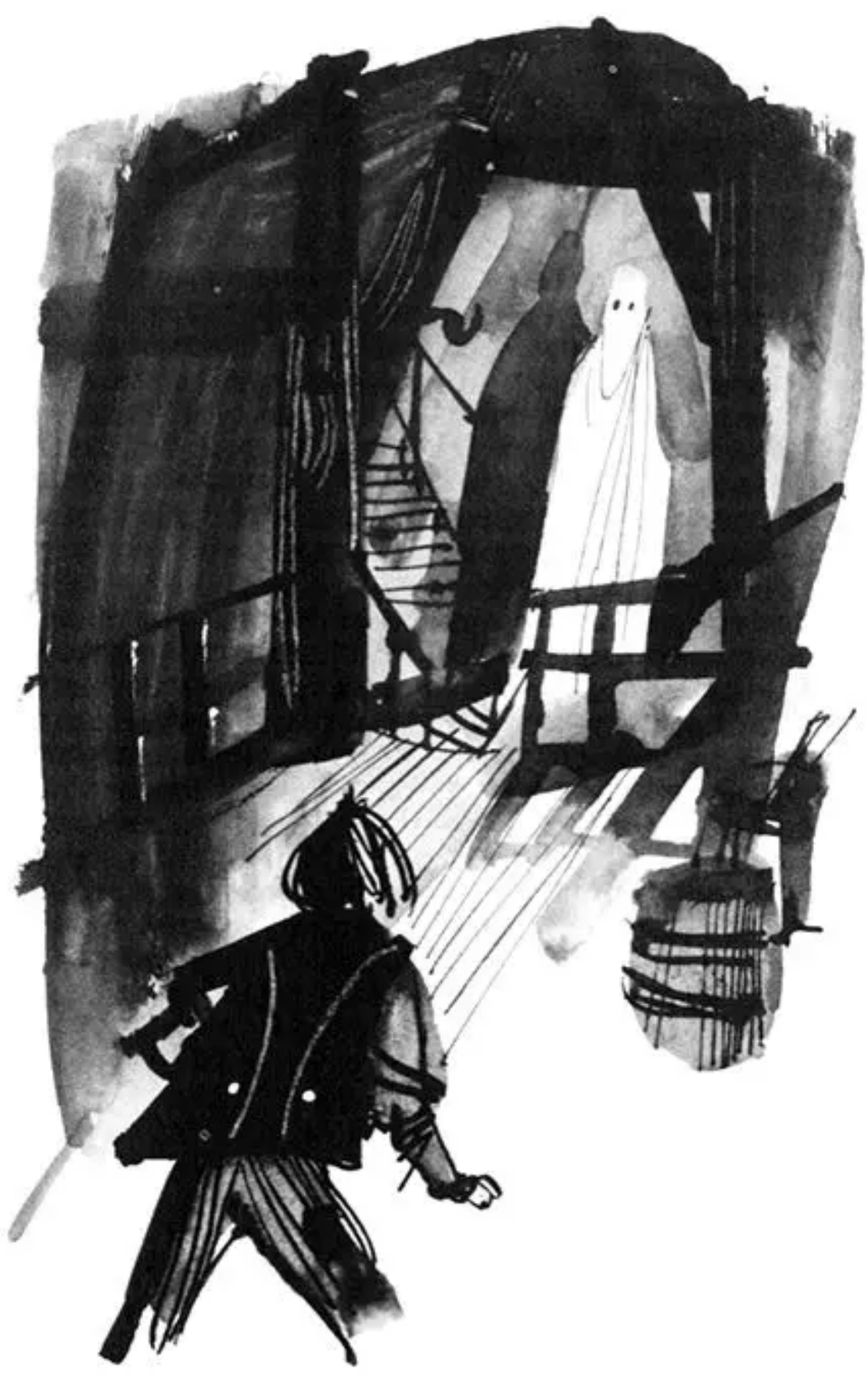

Fig. 4, Illustration for "The Story of the Youth Who Went Forth to Learn What Fear Was" by Kurt Schmischke (1976) ${ }^{6}$

\section{References}

1. Just two examples from a multitude of publications: Lars Koch (Hrsg.): Angst. Ein interdisziplinäres Handbuch, Stuttgart 2013, https://doi.org/10.1007/978-3-47605300-8; Joanna Bourke: Fear: A Cultural History, London 2005.

2. German: „Von einem der auszog, das Fürchten zu lernen“, Gebrüder Grimm, Kinder- und Hausmärchen (KHM) Nr. 4. 
3. „Märchen von einem, der auszog, das Fürchten zu lernen“:

https://www.deutschland-lese.de/streifzuege/maerchen/maerchen-von-einem-derauszog-das-fuerchten-zu-lernen/ (30.05.2021). Anm.: Die Bilder in dieser

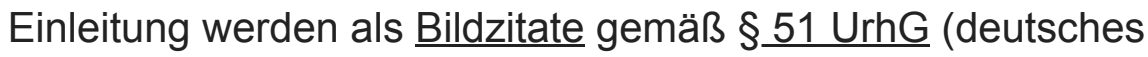

Urheberrechtsgesetz) ausschließlich zur inhaltlichen Erläuterung genutzt.

4. Illustrationen zum Märchen „Von einem, der auszog das Fürchten zu lernen“:

https://grimmbilder.fandom.com/de/wiki/M\%C3\%A4rchen_von_einem,_der_auszo

g_das_F\%C3\%BCrchten_zu_lernen_(lllustrationen)?

file=Von_einem_der_auszog_Marlene_Reidel_1975.jpg (30.05.2021).

5. Illustrationen zum Märchen „Von einem, der auszog das Fürchten zu lernen“:

https://grimmbilder.fandom.com/de/wiki/M\%C3\%A4rchen_von_einem,_der_auszo g_das_F\%C3\%BCrchten_zu_lernen_(Illustrationen)?

file=Von_einem_der_auszog_Albert_Weisgerber_um_1910.jpg (30.05.2021).

6. Illustrationen zum Märchen „Von einem, der auszog das Fürchten zu lernen“:

https://grimmbilder.fandom.com/de/wiki/M\%C3\%A4rchen_von_einem,_der_auszo

g_das_F\%C3\%BCrchten_zu_lernen_(lllustrationen)?

file=Von_einem_der_auszog_Kurt_Schmischke.jpg (30.05.2021).

SUGGESTED CITATION: Griem, Julika; Menn, Ricarda; Voßkamp, Sabine: Angst+ I

Fear+. Introducing a new blog series, in: KWI-BLOG,

[https://blog.kulturwissenschaften.de/angst-fear/], 09.06.2021

DOI: https://doi.org/10.37189/kwi-blog/20210609-0830 


\section{DuEPublico}

Dieser Text wird via DuEPublico, dem Dokumenten- und Publikationsserver der Universität Duisburg-Essen, zur Verfügung gestellt. Die hier veröffentlichte Version der E-Publikation kann von einer eventuell ebenfalls veröffentlichten Verlagsversion abweichen.

DOI: $\quad 10.37189 / \mathrm{kwi}-\mathrm{blog} / 20210609-0830$

URN: urn:nbn:de:hbz:464-20210610-114731-6 